\title{
Structure Analysis for Hydrate Models of Ethyleneimine Oligomer by Quantum Chemical Calculation
}

\author{
Minoru Kobayashi ${ }^{1}$, Hisaya Sato $^{2}$ \\ ${ }^{1}$ Graduate School of Bio-Applications and Systems Engineering, Tokyo University of Agriculture and Technology, Tokyo, Japan; \\ ${ }^{2}$ Graduate School of Technical Management, Tokyo University of Agriculture and Technology, Tokyo, Japan. \\ Email:mikoba3@aol.com
}

Received June $14^{\text {th }}, 2010$; revised July $14^{\text {th }}, 2010$; accepted August $10^{\text {th }}, 2010$.

\begin{abstract}
Structure analyses for hydrate models of ethyleneimine oligomer (5-mer as model of PEI) were investigated by quantum chemical calculations. Conformation energies and structures optimized for hydrate models of $(t t t)_{5}$ and $(\text { tgt })_{5}$ conformers were examined. Hydrate ratio, $h\left[h=H_{2} \mathrm{O} / \mathrm{N}(\mathrm{mol})\right]$, was set from 0.5 to 2 . In anhydrates, $\left(\mathrm{tg}^{+} t\right)_{5}$ conformer was more stable $(-1.8 \mathrm{kcal} / \mathrm{m} . u$. $)$ than $(\mathrm{ttt})_{5}$. In hydrates, $(\mathrm{ttt})_{5}$ conformers were more stable $(-0.7--4.3)$ than $\left(\operatorname{tg}^{+} t\right)_{5}$. These results corresponded to experimental results that anhydrous linear PEI crystal changes from double helical to single planar chain in hydration process. Structures calculated for $(t t t)_{5}$ agreed in those observed for hydrates of PEI. In all $\left(\operatorname{tg}^{+} t\right)_{5}$ conformers, $O \cdots H$ bonds between waters were found with the decreases of $N \cdots H$ bonds between imino group and water. The $O \cdots H$ bonds in $\left(\operatorname{tg}^{+} t\right)_{5}$ conformer resulted in its high chain torsion, and strongly related with instability and structure change (large swelling).
\end{abstract}

Keywords: Structure Analysis, Conformation, Hydrate, Poly(Ethyleneimine), Oligomer, Quantum Chemical Calculation

\section{Introduction}

Linear poly(ethyleneimine) (PEI, $\left.\left(-\mathrm{CH}_{2} \mathrm{CH}_{2} \mathrm{NH}-\right)_{\mathrm{n}}\right)$ exhibits various kinds of crystalline phases. X-Ray diffraction (XRD) [1-3] and time-resolved infrared spectral measurement [4] have confirmed that the structure of anhydrate is a $5 / 1$ double stranded helix with a repeating tgt (t: trans, g: gauche) conformation for N-C, C-C, and $\mathrm{C}-\mathrm{N}$ bonds, and in the hydrate, the structure transforms to the planar zigzag with ttt conformation. In hydration process, the anhydrate changes to the hemi-hydrate $\left(\mathrm{H}_{2} \mathrm{O} / \mathrm{EI}=0.5 / 1 \mathrm{~mol}\right)$, subsequently the sesqui-hydrate $\left(\mathrm{H}_{2} \mathrm{O} / \mathrm{EI}=1.5 / 1\right)$, and finally the di-hydrate $\left(\mathrm{H}_{2} \mathrm{O} / \mathrm{EI}=\right.$ $2 / 1$ ) with increasing water contents. The mechanism of such characteristic transitions, however, is not yet clear. The understanding of the mechanism is important also in relation with the biological problem of double stranded DNA chains.

To complement the experimental observations in the conformations of PEI, computational chemistry has been employed. Analyses for anhydrate models using molecular mechanics (MM) and molecular dynamics (MD) have been reported [5,6]. Furthermore, recent studies involve quantum chemical calculations method (QCC) [7-9]. The reports concerning an analysis using hydrate model of PEI, however, seem to be little [10]. We have investigated the conformation analyses for EI oligomer models by QCC [11-12]. Most recently, for the hydrate models with various conformations $\left((t t t)_{x},\left(\operatorname{tgg}^{+}\right)_{\mathrm{x}},\left(\operatorname{tg}^{+} \mathrm{t}\right)_{\mathrm{x}},\left(\operatorname{tg}^{+} \mathrm{g}^{+}\right)_{\mathrm{x}}\right.$, $\left(\operatorname{tg}^{+} \mathrm{g}^{-}\right)_{\mathrm{x}}$, and $\left(\mathrm{g}^{+} \mathrm{g}^{+} \mathrm{g}^{+}\right)_{\mathrm{x}}, \mathrm{x}$ : monomer units number; $\mathrm{x}=1-$ 8) of EI oligomers, we reported [13] that the $\left(\operatorname{tg}^{+} t\right)_{x}$ and $(\mathrm{ttt})_{\mathrm{x}}$ conformers are the most stable in anhydrate and hydrate (hydrate ratio: $\mathrm{h}\left(\mathrm{H}_{2} \mathrm{O} / \mathrm{N}(\mathrm{mol})=1\right)$, respectively, and the stabilities of conformers seemed to be related with hydrogen bonding between water molecules. However, the details of mechanism in such transfer from $\left(\operatorname{tg}^{+} t\right)_{\mathrm{x}}$ to $(\mathrm{ttt})_{\mathrm{x}}$ were not yet clear.

In this study, in order to deepen an understanding to the mechanism of such transfer of PEI in hydration process, the structure analyses for hydrate models of EI oligomer were investigated by QCC in more detail. The 5 -mer model (single chain) as PEI model was used. The conformation energies and structures of only the $(\mathrm{ttt})_{5}$ or $(\operatorname{tgt})_{5}$ conformer with various hydrate ratios were esti- 
mated from the optimized structures. The conformational characteristics of hydrates were discussed, and were compared with the experimental results observed for PEI's crystals in hydration process.

\section{Calculation}

\subsection{Designations of Anhydrate Models}

For anhydrate model, EI 5-mer capped with N-methylimino and methyl group (single chain: $\mathrm{CH}_{3} \mathrm{NH}-\left(\mathrm{CH}_{2} \mathrm{CH}_{2} \mathrm{NH}\right)_{5}-$ $\mathrm{CH}_{3}$ ) was used. For its conformation, the (ttt) $)_{5}$ and $(\operatorname{tgt})_{5}$ conformers were prepared. The conformations: $\left(\tau_{\mathrm{n}} \tau_{\mathrm{n}+1}\right.$ $\left.\tau_{\mathrm{n}+2}\right)_{\mathrm{x}=5}(\tau$ : dihedral angles, $\mathrm{n}$ : sequential number of atoms along a skeletal chain, $\mathrm{x}$ : monomer units number) were designated for the combination of $\tau$ that are repeated for the units of $\mathrm{N}-\mathrm{C}, \mathrm{C}-\mathrm{C}$, and $\mathrm{C}-\mathrm{N}$ bonds. Every dihedral angle was independently assigned along the skeletal chains. The descriptive example designated for the model (EI 1-mer) as ethyleneimine monomer is given in Figure 1. As reported in our previous paper [11], the conformation energies optimized for anhydrate models of EI oligomers (1 - 11-mer) using QCC (by RHF/6-31 + $\mathrm{G}(\mathrm{d}, \mathrm{p})$ basis set) affected by the designation values for the trans conformation. All the most stable conformers were obtained by using the designation values for trans as follow: $\left(\tau_{\mathrm{n}} / \tau_{\mathrm{n}+1} / \tau_{\mathrm{n}+2}\right)_{\mathrm{x}}$ was $\left(-175^{\circ} /-175^{\circ} / 180^{\circ}(\pi)\right)_{\mathrm{x}}$, whose pseudo-asymmetries based on a nitrogen inversion were racemo. This designation system is partially restricted system, which was defined as that restricted from $\pi$ to a unidirectional angle as trans helical condition. In this study, therefore, this system was used for the design- nations of trans values of dihedral angle. For the $\left(\operatorname{tg}^{+} \mathrm{t}\right)_{5}$ conformer, $\left(-170^{\circ} /+60^{\circ} / 180^{\circ}(\pi)\right)_{\mathrm{x}=5}$ was used as $\left(\tau_{\mathrm{n}} / \tau_{\mathrm{n}+1} /\right.$ $\left.\tau_{\mathrm{n}+2}\right)_{\mathrm{x}=5}$ value.

\subsection{Designations of Hydrate Models}

Hydrate models were prepared by locating water molecule near the nitrogen atom in the optimized structures for anhydrate. The optimization for anhydrate was carried out firstly using RHF/STO-3G and then RHF/6-31G basis sets. The specified models are given in Table 1. Hydrate ratio (h) was defined by $\mathrm{H}_{2} \mathrm{O}_{\text {mol }} / \mathrm{N}_{\text {mol in oligomer, }}$ and the values of 0.5-2 were set. Two types of models were used: in one model water molecules are attached to discontinuous monomer units ( $\alpha$ type) and in the other to continuous monomer units ( $\beta$ type) as shown in Table 1. The structure designated for EI 1-mer as a descriptive example is given in Figure 1. Hydrate distance $\left(\mathrm{d}_{\mathrm{N}-\mathrm{H}},(\AA)\right)$ was defined by the unbonded distance between the nearest nitrogen atom $(\mathrm{N})$ and hydrogen atom $(\mathrm{H})$ of $\mathrm{HOH}^{\prime}$ in which $\mathrm{H}$ atom is closer to the nitrogen atom than $\mathrm{H}^{\prime}$ atom as shown in Figure 1. For all conformers except for the $\left(\operatorname{tg}^{+} \mathrm{t}\right)_{5}$ conformers with $\mathrm{h}=1.5$ and 2 , the value of $1.7 \AA$ was used as $\mathrm{d}_{\mathrm{N}-\mathrm{H}}$, according to the results in our previous report [13] in which the effects of designations of $d_{N-H}$ on the optimized structures were examined to the experimental results. In the $\left(\operatorname{tg}^{+} t\right)_{5}$ conformers with $\mathrm{h}=1.5$ and 2 , the $\mathrm{d}_{\mathrm{N}-\mathrm{H}}$ values of 1.7 and $5.2 \AA$ for a di-hydrate $\mathrm{NH}$ unit were used in order to avoid a crowding of water molecules in designation structure. The direction effects in location of water molecule (to $\mathrm{N}$ or $\mathrm{H}$ in $\mathrm{NH}$ group) on the optimized structures and energies were not found.
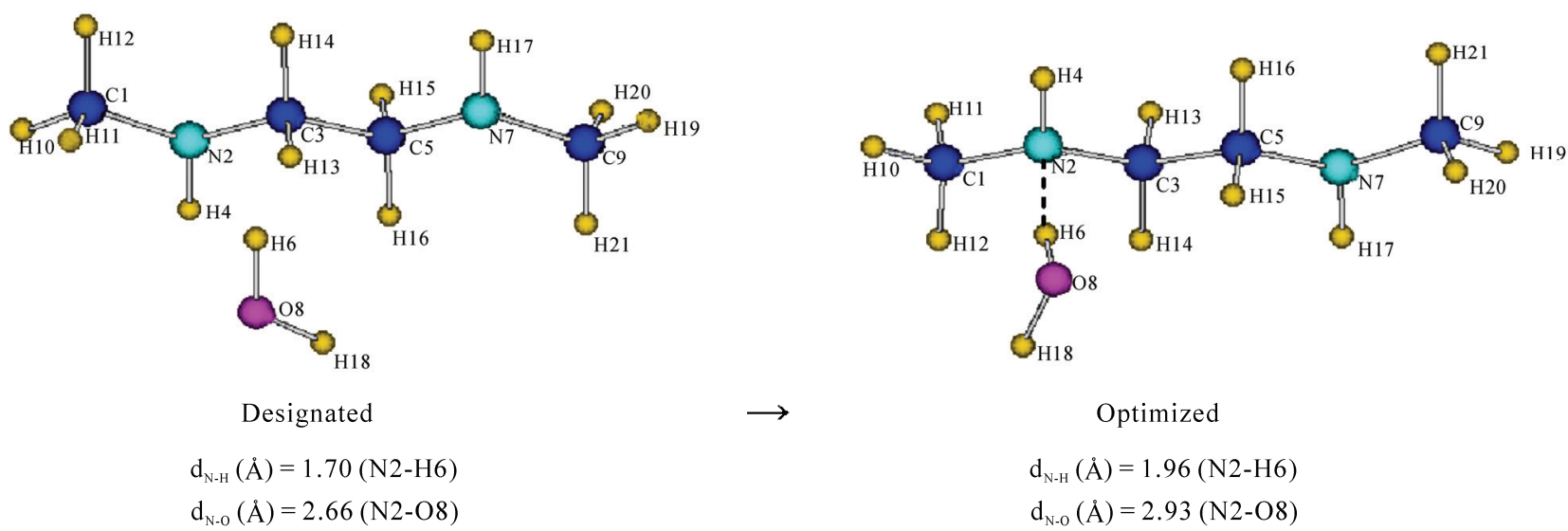

$$
\begin{gathered}
\text { Designated } \\
\mathrm{d}_{\mathrm{N}-\mathrm{H}}(\AA)=1.70(\mathrm{~N} 2-\mathrm{H} 6) \\
\mathrm{d}_{\mathrm{N}-\mathrm{O}}(\AA)=2.66(\mathrm{~N} 2-\mathrm{O} 8)
\end{gathered}
$$

Figure 1. Descriptive examples of designated and optimized structures for hydrate model of ethylenimine monomer (EI 1-mer, conformation: $(\mathrm{ttt})_{1}, \mathrm{~h}=\mathbf{0 . 5}, \alpha$ type, (--: hydrogen bond). Conformation was defined by $\left(\tau_{\mathrm{n}} \tau_{\mathrm{n}+1} \tau_{\mathrm{n}+2}\right)_{\mathrm{x}=1}$, where $\tau_{\mathrm{n}}$, $\tau_{\mathrm{n}+1}$, and $\tau_{\mathrm{n}+2}$ are the dihedral angles $\left({ }^{\circ}\right)$ for $\mathrm{N}-\mathrm{C}, \mathrm{C}-\mathrm{C}$, and $\mathrm{C}-\mathrm{N}$ bonds, respectively, and $\mathrm{x}$ is monomer unit number. In "Dseignated" of the figure, $-175^{\circ},-175^{\circ}$, and $\pi$ as the dihedral angles $\left(\tau_{n}, \tau_{n+1}\right.$, and $\tau_{n+2}$ : partially restricted system) were used for $N 2-C 3$, C3-C5, and C5-N7 bonds, respectively. Hydrate distance $\left(\mathrm{d}_{\mathrm{N}-\mathrm{H}},(\AA)\right)$ was defined in hydrogen bonded NH group and water $(\mathrm{N} \cdots \mathrm{H}, \mathrm{N2}-\mathrm{H6})$ as shown in "Optimized" in the figure. Conformer length was defined by $\mathrm{L}(\AA)$, where $\mathrm{L}$ is unbonded distance between the terminal nitrogen atoms: $\mathrm{N} 2-\mathrm{N} 7$ in the figure. 
Table 1. Hydrate models for ethyleneimine oligomer (EI 5mer).

\begin{tabular}{|c|c|c|c|}
\hline $\begin{array}{l}\text { Hydrate models }{ }^{1} \\
\text { No. Models }\end{array}$ & $\begin{array}{l}\text { Hydrate } \\
\text { type }\end{array}$ & $\begin{array}{l}\text { Number of } \\
\mathrm{H}_{2} \mathrm{O}: \mathrm{N}_{\mathrm{w}}\end{array}$ & $\begin{array}{l}\text { Hydrate ratio: } \\
\text { h }\left(\mathrm{H}_{2} \mathrm{O} / \mathrm{N}, \mathrm{mol}\right)\end{array}$ \\
\hline $1 \mathrm{~N}-\mathrm{N}-\mathrm{N}-\mathrm{N}-\mathrm{N}-\mathrm{N}$ & - & 0 & 0.000 \\
\hline $2 \underline{\mathrm{N}}-\mathrm{N}-\mathrm{N}-\mathrm{N}-\underline{\mathrm{N}}-\mathrm{N}$ & $\alpha$ & 3 & 0.500 \\
\hline $3 \mathrm{~N}-\underline{\mathrm{N}}-\underline{\mathrm{N}}-\underline{\mathrm{N}}-\mathrm{N}-\mathrm{N}$ & $\beta$ & 3 & 0.500 \\
\hline $4 \mathrm{~N}-\underline{\mathrm{N}}-\underline{\underline{N}}-\underline{\underline{N}}-\underline{\mathrm{N}}-\mathrm{N}$ & $\beta$ & 4 & 0.667 \\
\hline $5 \mathrm{~N}-\underline{\mathrm{N}}-\underline{\mathrm{N}}-\underline{\mathrm{N}}-\underline{\mathrm{N}}-\underline{\mathrm{N}}$ & $\beta$ & 5 & 0.833 \\
\hline $6 \underline{\mathrm{N}}-\underline{\mathrm{N}}-\underline{\mathrm{N}}-\underline{\mathrm{N}}-\underline{\mathrm{N}}-\underline{\mathrm{N}}$ & $\beta$ & 6 & 1.000 \\
\hline $7 \underline{\mathrm{N}}-\underline{\mathrm{N}}-\underline{\mathrm{N}}-\underline{\mathrm{N}}-\underline{\mathrm{N}}-\underline{\mathrm{N}}$ & $\beta$ & 9 & 1.500 \\
\hline $8 \underline{\underline{N}}-\underline{N}-\underline{N}-\underline{N}-\underline{N}-\underline{N}$ & $\beta$ & 12 & 2.000 \\
\hline
\end{tabular}

${ }^{1} \underline{\mathrm{N}}$ and $\underline{\mathrm{N}}$ show the mono- and di-hydrated nitrogen units, respectively, $(\mathrm{N}=$ RNHR', $\mathrm{R}$ or $\mathrm{R}^{\prime}=\mathrm{CH}_{3}$ or $\mathrm{CH}_{2} \mathrm{CH}_{2}$ ). The $\alpha$ and $\beta$ show discontinuous and continuous hydrate units, respectively.

\subsection{Structure Optimizations}

Structure optimizations were carried out for each model using QCC via the Gaussian 03W (Gaussian Inc.) program [14], according to the methods in our previous report [13]. RHF/6-31G basis set was used. Gross energy of hydrated conformer with waters, $\mathrm{E}_{\mathrm{h}}$ (Hartree, 1 Hartree $=627.51 \mathrm{kcal} / \mathrm{mol})$, was calculated. Conformation energy of conformer, $\mathrm{E}_{\mathrm{c}}$ (Hartree) was calculated via Equations (1) and (2),

$$
\begin{aligned}
& E_{c}=E_{h}-\sum E_{w} \\
& \sum E_{w}=E_{w(n)}+E_{w(h)}
\end{aligned}
$$

where $\sum E_{w}$ is the total energy of water molecules. $\mathrm{E}_{\mathrm{w}(\mathrm{n})}$ and $E_{w(h)}$ are the energies of non-hydrogen and hydrogen bonded water molecules, respectively.

The $E_{w(n)}$ was calculated for the model of non-hydrogen bonded water molecules which are consisted of $n$ units of single water molecule by RHF/6-31G basis set (refer Table 2). As the unit number $(n)$ in the calculation of $E_{w(n)}$, the number of water molecules $\left(N_{w(n)}\right)$ with non-hydrogen bonded water molecules, which was estimated in the structures optimized for the hydrate models, was used (refer Table 4, Figure 2 and Figure 3). In the same way, the $E_{w(h)}$ was calculated for the model of linearly hydrogen bonded water molecules which are consisted of $n$ units of sequential water molecules. As $n$ in the calculation of $E_{w(h)}$, the number of water molecules $\left(N_{w(h)}\right)$ with hydrogen bonded water molecules was used. Hydrogen bond $(\mathrm{O} \cdots \mathrm{H}$ bond) between water molecules was confirmed by the unbonded $\mathrm{O} \cdots \mathrm{O}$ distance $\left(\mathrm{d}_{\mathrm{O}-\mathrm{O}}\right)$ between water molecules. The $\mathrm{d}_{\mathrm{O}-\mathrm{O}}$ values in non-hydro-
Table 2. Energies $\left(E_{w}, H F\right)$ calculated for water molecules

\begin{tabular}{|c|c|c|c|c|c|}
\hline$n^{1}$ & $E_{w(n)}^{2}$ & $E_{w(h)}^{3}$ & $n^{1}$ & $E_{w(n)}^{2}$ & $E_{w(h)^{3}}$ \\
\hline 1 & -75.9854 & - & 5 & -379.9274 & -379.9876 \\
\hline 2 & -151.9708 & -151.9826 & 6 & -455.9128 & -455.9907 \\
\hline 3 & -227.9562 & -227.9830 & 9 & -683.8686 & -684.0007 \\
\hline 4 & -303.9416 & -303.9850 & 12 & -911.8256 & -912.0114 \\
\hline
\end{tabular}
by RHF/6-31G.

gen and hydrogen bonded water molecules were defined as the larger and smaller value than $3 \AA$, respectively, according to the results observed for water dimer $\left(\mathrm{d}_{\mathrm{O}-\mathrm{O}}\right.$ : $2.74 \AA$ in regular ice [15], $2.85 \AA$ in liquid [15], and 2.98 $\AA$ in vapor $[16,17])$. The $\mathrm{d}_{\mathrm{O}-\mathrm{O}}$ values in $\mathrm{O} \cdots \mathrm{H}$ bonded water molecules estimated for the models of water molecules were smaller than $3 \AA$. The calculated $E_{w(n)}$ and $E_{w(h)}$ values are given in Table 2. The examples for conformation energies $\left(E_{c}\right)$ are given in Table 3.

The conformation in optimized structure was specified based on IUPAC [18] as follow: $\tau_{\mathrm{n}}$ of trans $\left(\mathrm{t}^{ \pm}\right)$and gauche $\left(\mathrm{g}^{ \pm}\right)$are from $\pm 120^{\circ}$ to $\pm 180^{\circ}$ and from $\pm 0^{\circ}$ to \pm $120^{\circ}$, respectively. Hydrate distance $\left(\mathrm{d}_{\mathrm{N}-\mathrm{H}},(\AA)\right)$ was defined as mentioned before, and its example is shown in Figure 1. Another parameter for hydrate distance was defined by $\mathrm{d}_{\mathrm{N}-\mathrm{O}}(\AA)$, where $\mathrm{d}_{\mathrm{N}-\mathrm{O}}$ is unbonded distance between nitrogen atom $(\mathrm{N})$ of imino group and oxygen atom $(\mathrm{O})$ of neighboring water molecule. The $\mathrm{d}_{\mathrm{N}-\mathrm{O}}$ value in hydrogen bonded ( $\mathrm{N} \cdots \mathrm{H}$ bond) imino group/water molecule was defined as smaller value than $3 \AA\left(\mathrm{d}_{\mathrm{N}-\mathrm{H}}<2\right.$ $\AA$ ) according to the results observed for hydrous PEI's crystals $\left(\mathrm{d}_{\mathrm{N}-\mathrm{O}}: 2.87\right.$ - $3.05[2,3]$, see Table 5). Conformer length was defined by $\mathrm{L}(\AA)$, where $\mathrm{L}$ is unbonded distance between terminal nitrogen atoms as shown in footnote of Figure 1. Diameter of $(\operatorname{tgt})_{5}$ conformer was defined by $D(\AA)$, where $D$ is relative diameter which was measured as the largest value in chain axis projection for optimized structure based on D value of anhydrate.

\section{Results and Discussion}

\subsection{Conformation Energies (Ec) Calculated for Hydrate Models of (ttt)5 and (tg+t)5 Conformers}

The structures optimized for the hydrate models of $(\mathrm{ttt})_{5}$ and $\left(\operatorname{tg}^{+} t\right)_{5}$ conformers of EI 5-mer as model of PEI were examined. In Figures $\mathbf{2}$ and 3, the examples of structures optimized for $(\mathrm{ttt})_{5}$ and $\left(\mathrm{tg}^{+} \mathrm{t}\right)_{5}$ conformers are shown, respectively. In both figures, the hydrogen bonds with 

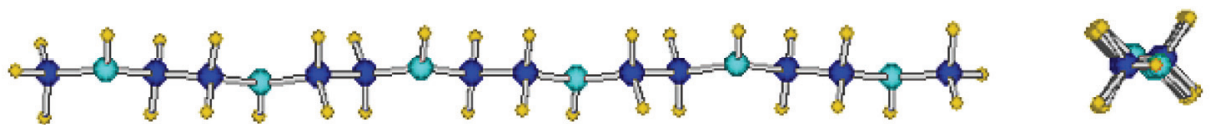

$\mathrm{h}=0$
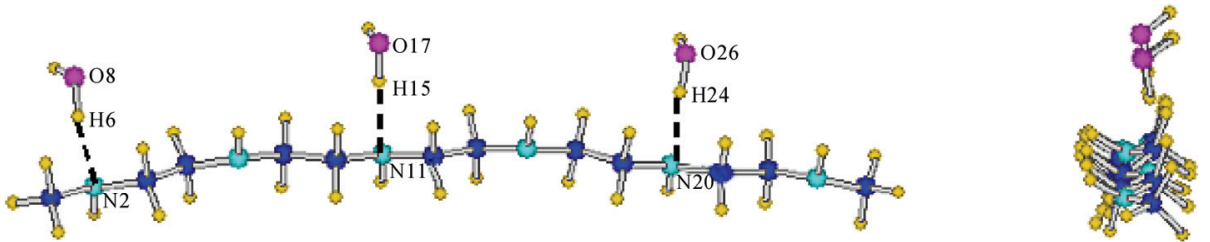

$\mathrm{d}_{\mathrm{N}-\mathrm{H}}(\AA): \mathrm{N} 2-\mathrm{H} 6=1.93, \mathrm{~N} 11-\mathrm{H} 15=1.94, \mathrm{~N} 20-\mathrm{H} 24=1.93$
$\mathrm{~d}_{\mathrm{N}-\mathrm{O}}(\AA): \mathrm{N} 2-\mathrm{O} 8=2.88, \mathrm{~N} 11-\mathrm{O} 17=2.88, \mathrm{~N} 20-\mathrm{O} 26=2.88$
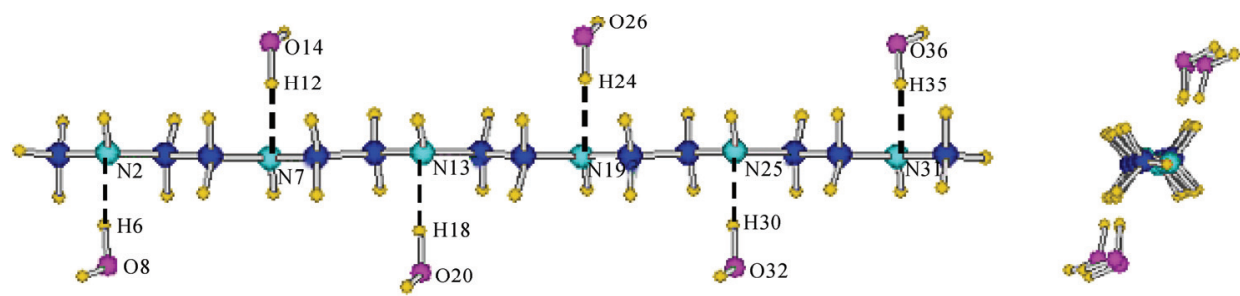

$\mathrm{h}=0.5, \alpha$

$\mathrm{d}_{\mathrm{N}-\mathrm{H}}(\AA): \mathrm{N} 2-\mathrm{H} 6=1.93, \mathrm{~N} 7-\mathrm{H} 12=1.93, \mathrm{~N} 13-\mathrm{H} 18=1.93, \mathrm{~N} 19-\mathrm{H} 24=1.94, \mathrm{~N} 25-\mathrm{H} 30=1.93, \mathrm{~N} 31-\mathrm{H} 35=1.93$,

$\mathrm{d}_{\mathrm{N}-\mathrm{O}}(\AA): \mathrm{N} 2-\mathrm{O} 8=2.88, \mathrm{~N} 7-\mathrm{O} 14=2.88, \mathrm{~N} 13-\mathrm{O} 20=2.87, \mathrm{~N} 19-\mathrm{O} 26=2.87, \mathrm{~N} 25-\mathrm{O} 32=2.88, \mathrm{~N} 31-\mathrm{O} 36=2.88$.
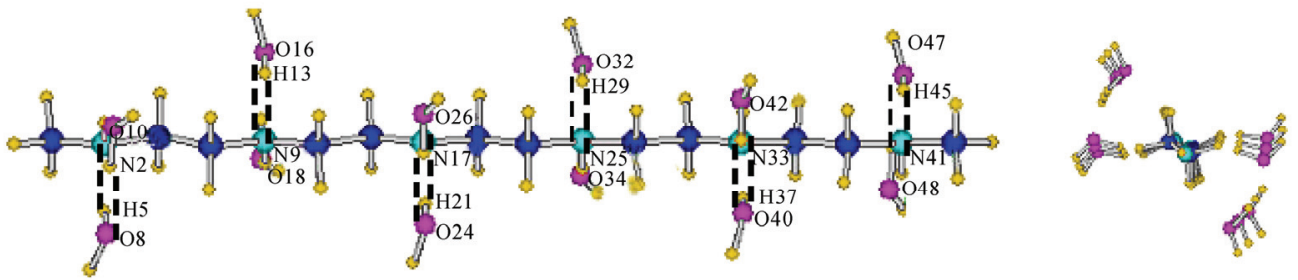

$\mathrm{h}=2, \beta$

$\mathrm{d}_{\mathrm{N}-\mathrm{H}}(\AA): \mathrm{N} 2-\mathrm{H} 1=1.88, \mathrm{~N} 9-\mathrm{H} 13=1.89, \mathrm{~N} 17-\mathrm{H} 21=1.89, \mathrm{~N} 25-\mathrm{H} 29=1.89, \mathrm{~N} 33-\mathrm{H} 37=1.89, \mathrm{~N} 11-\mathrm{H} 15=1.88$,

$\mathrm{d}_{\mathrm{N}-\mathrm{O}}(\AA): \mathrm{N} 2-\mathrm{O} 8=2.80, \mathrm{~N} 9-\mathrm{O} 16=2.80, \mathrm{~N} 17-\mathrm{O} 24=2.81, \mathrm{~N} 25-\mathrm{O} 32=2.81, \mathrm{~N} 33-\mathrm{O} 40=2.81, \mathrm{~N} 41-\mathrm{O} 47=2.80$,

$\mathrm{d}_{\mathrm{N}-\mathrm{O}}(\AA): \mathrm{O} 8-\mathrm{O} 10=2.72, \mathrm{O} 16-\mathrm{O} 18=2.73, \mathrm{O} 24-\mathrm{O} 26=2.72, \mathrm{O} 32-\mathrm{O} 34=2.73, \mathrm{O} 40-\mathrm{O} 42=2.72, \mathrm{O} 47-\mathrm{O} 48=2.72$.

Figure 2. Structures optimized for hydrate models of (ttt) $)_{5}$ conformer of EI 5-mer by RHF/6-31G. Left and right side figures show the stereo oblique and chain axis projections, respectively. (---: hydrogen bonds, $d_{\mathrm{N}-\mathrm{H}}\left(d_{\mathrm{N}-\mathrm{O}}\right)$ : unbonded distances in hydrogen bonded $\mathrm{NH}$ group/water, $\mathrm{d}_{\mathrm{O}-\mathrm{O}}$ : unbonded distances in hydrogen bonded water/water).

water molecules are specified as follows: the $\mathrm{N} \cdots \mathrm{H}$ bond between imino group and water molecule $(\mathrm{N} \cdots \mathrm{H}$ bond, $\mathrm{d}_{\mathrm{N}-\mathrm{H}}<2 \AA$ and $\mathrm{d}_{\mathrm{N}-\mathrm{O}}<3 \AA$ ) and the $\mathrm{O} \cdots \mathrm{H}$ bond between water molecules $\left(\mathrm{O} \cdots \mathrm{H}\right.$ bond, $\mathrm{d}_{\mathrm{O}-\mathrm{O}}<3 \AA$ ) are shown with the $\mathrm{d}_{\mathrm{N}-\mathrm{H}}, \mathrm{d}_{\mathrm{N}-\mathrm{O}}$ and $\mathrm{d}_{\mathrm{O}-\mathrm{O}}$ values. In $(\mathrm{ttt})_{5}$ conformers with $\mathrm{h}$ $=0.5$ and 1, as shown in Figure 2, the hydrogen bond with water molecule is only $\mathrm{N} \cdots \mathrm{H}$ bond, and the $\mathrm{O} \cdots \mathrm{H}$ bond is nothing. The number of water molecules with $\mathrm{N} \cdots \mathrm{H}$ bond $\left(\mathrm{N}_{\mathrm{w}\left(\mathrm{h}^{\prime}\right)}\right)$ increases (3 to 6) with increases $(0.5$ to 1 ) of $\mathrm{h}$ values. In $(\mathrm{ttt})_{5}$ conformers with $\mathrm{h}=2$, as shown in Figure 2, both $\mathrm{N} \cdots \mathrm{H}$ and $\mathrm{O} \cdots \mathrm{H}$ bonds are found in each pair of imino group and water molecules, and the $\mathrm{N}_{\mathrm{w}\left(\mathrm{h}^{\prime}\right)}$ and the number of water molecules with $\mathrm{O} \cdots \mathrm{H}$ bond $\left(\mathrm{N}_{\mathrm{w}(\mathrm{h})}\right)$ are 6 and $12(2 \times 6, \mathrm{n}=2)$, respectively. On the other hand, in $\left(\operatorname{tg}^{+} \mathrm{t}\right)_{5}$ conformers, the $\mathrm{N} \cdots \mathrm{H}$ and $\mathrm{O} \cdots \mathrm{H}$ bonds are found in all conformers as shown in Figure 3. For example, in $\left(\operatorname{tg}^{+} \mathrm{t}\right)_{5}$ conformers with $\mathrm{h}=0.5$ (discontinuous hydrate type: $\alpha$ ), the $\mathrm{N}_{\mathrm{w}\left(\mathrm{h}^{\prime}\right)}$ and $\mathrm{N}_{\mathrm{w}(\mathrm{h})}$ values are 3 and 2, respectively..$\AA$

The conformation energy $\left(E_{c}\right)$ of hydrate conformer was estimated as the difference between the gross energy of hydrated conformer with waters $\left(E_{h}\right)$ and the total energy of water molecules $\left(\sum \mathrm{E}_{\mathrm{w}}\right)$ using Equations (1) and (2) as mentioned in previous section. The examples of conformation energies $\left(E_{c}\right)$ are shown in Table 3. The $E_{c}$ values were calculated using the number of water molecules with non-hydrogen and/or hydrogen bond $\left(\mathrm{N}_{\mathrm{w}(\mathrm{n})}\right.$ and/or $\mathrm{N}_{\mathrm{w}(\mathrm{h})}$ ) obtained in Figures 2 and 3. All results are summarized in Table 4.

Conformation energy for the most stable hydrate con- 

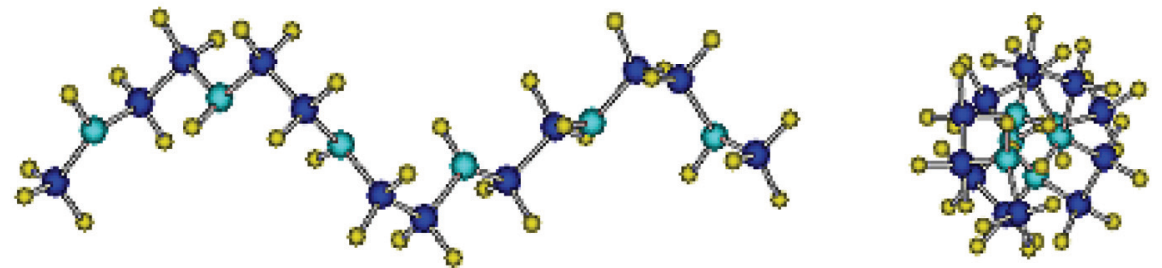

$\mathrm{h}=0$
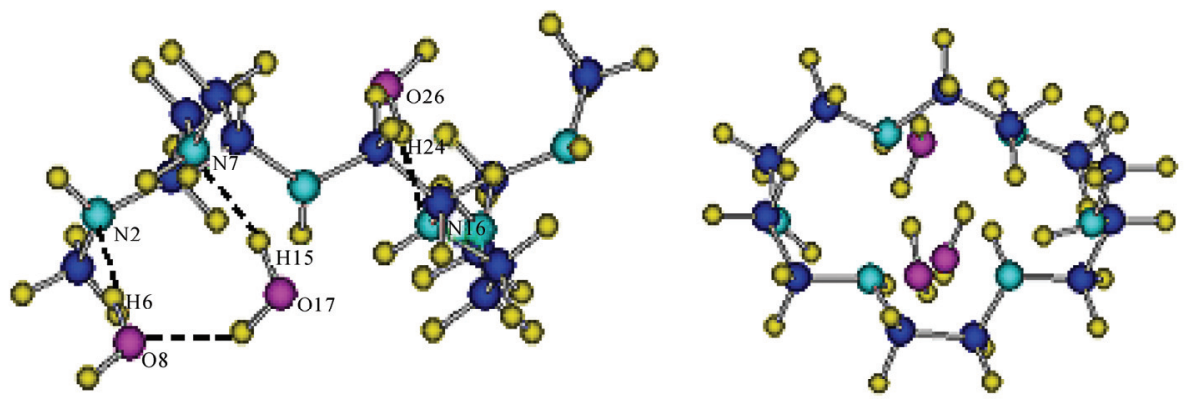

$\mathrm{d}_{\mathrm{N}-\mathrm{H}}(\AA): \mathrm{N} 2-\mathrm{H} 6=1.90, \mathrm{~N} 7-\mathrm{H} 15=1.94, \mathrm{~N} 16-\mathrm{H} 24=1.90$,

$\mathrm{d}_{\mathrm{N}-\mathrm{O}}(\AA): \mathrm{N} 2-\mathrm{O} 8=2.86, \mathrm{~N} 7-\mathrm{O} 17=2.89, \mathrm{~N} 16-\mathrm{O} 26=2.87$,

$\mathrm{d}_{\mathrm{N}-\mathrm{O}}(\AA): 08-\mathrm{O} 17=2.80$.
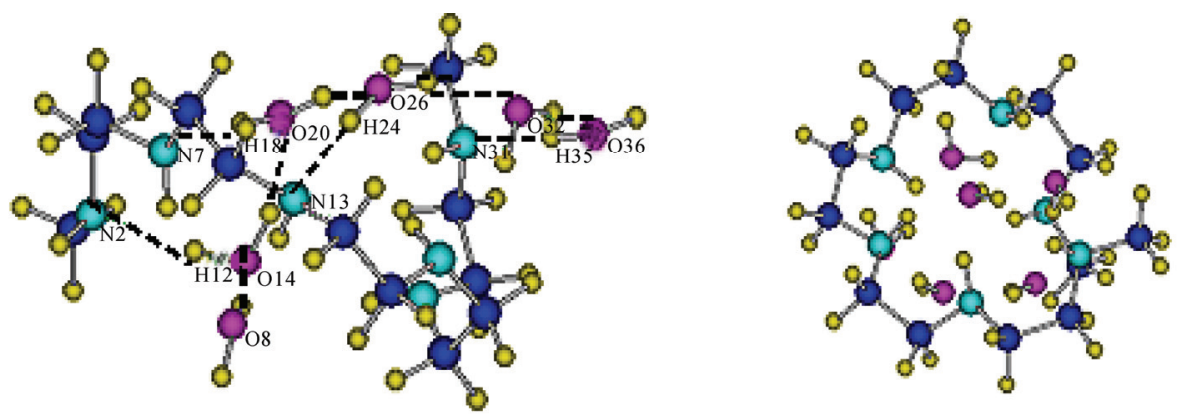

$\mathrm{d}_{\mathrm{N}-\mathrm{H}}(\AA): \mathrm{N} 2-\mathrm{H} 12=2.00, \mathrm{~N} 7-\mathrm{H} 18=1.93, \mathrm{~N} 13-\mathrm{H} 24=1.99, \mathrm{~N} 31-\mathrm{H} 35=1.83$,

$\mathrm{d}_{\mathrm{N}-\mathrm{O}}(\AA): \mathrm{N} 2-\mathrm{O} 14-2.95, \mathrm{~N} 7-\mathrm{O} 20-2.89, \mathrm{~N} 13-\mathrm{O} 26-2.95, \mathrm{~N} 31-\mathrm{O} 36-2.79$,

$\mathrm{d}_{\mathrm{N}-\mathrm{O}}(\AA): \mathrm{O} 8-\mathrm{O} 14=2.76, \mathrm{O} 14-\mathrm{O} 20=2.71, \mathrm{O} 20-\mathrm{O} 26=2.71, \mathrm{O} 26-\mathrm{O} 32=2.75, \mathrm{O} 32-\mathrm{O} 36=2.76$.
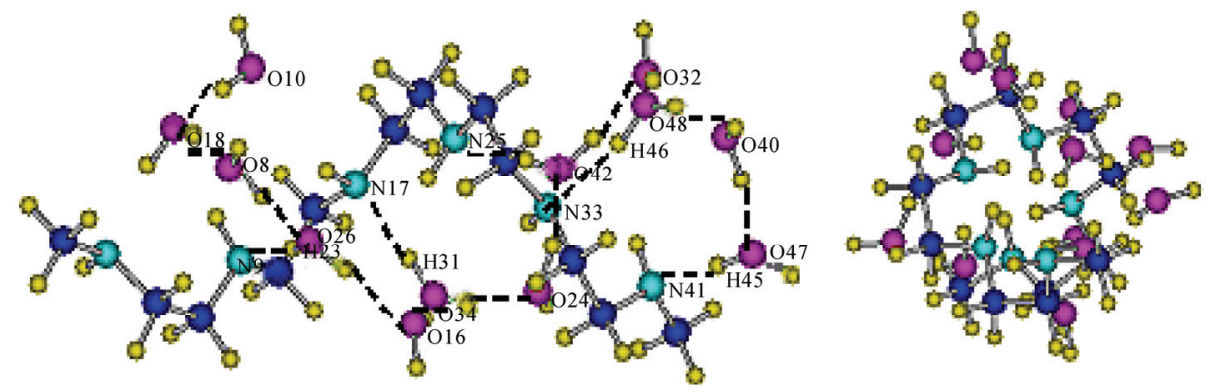

$$
\begin{aligned}
\mathrm{d}_{\mathrm{N}-\mathrm{H}}(\AA): & \mathrm{N} 9-\mathrm{H} 23=1.99, \mathrm{~N} 17-\mathrm{H} 31=1.94, \mathrm{~N} 25-\mathrm{H} 39=1.98, \mathrm{~N} 33-\mathrm{H} 46=2.00, \mathrm{~N} 41-\mathrm{H} 45=1.79, \\
\mathrm{~d}_{\mathrm{N}-\mathrm{O}}(\AA): & \mathrm{N} 9-\mathrm{O} 26=2.94, \mathrm{~N} 17-\mathrm{O} 34=2.91, \mathrm{~N} 25-\mathrm{O} 42=2.94, \mathrm{~N} 33-\mathrm{O} 48=2.94, \mathrm{~N} 41-\mathrm{O} 47=2.77, \\
\mathrm{~d}_{\mathrm{N}-\mathrm{O}}(\AA): & \mathrm{O} 10-\mathrm{O} 18=2.69, \mathrm{O} 18-\mathrm{O} 8=2.71, \mathrm{O} 8-\mathrm{O} 26=2.62, \mathrm{O} 26-\mathrm{O} 16=2.74, \mathrm{O} 16-\mathrm{O} 34=2.61, \mathrm{O} 34-\mathrm{O} 24=2.71, \\
& \mathrm{O} 24-\mathrm{O} 42=2.61, \mathrm{O} 42-\mathrm{O} 32=2.71, \mathrm{O} 32-\mathrm{O} 48=2.62, \mathrm{O} 48-\mathrm{O} 40=2.71, \mathrm{O} 40-\mathrm{O} 47=2.66 .
\end{aligned}
$$

Figure 3. Structures optimized for hydrate models of $\left(\operatorname{tg}^{+} t\right)_{5}$ conformer of EI 5-mer by RHF/6-31G. Left and right side figures show the stereo oblique and chain axis projections, respectively. (---: hydrogen bond, $d_{\mathrm{N}-\mathrm{H}}\left(\mathrm{d}_{\mathrm{N}-\mathrm{O}}\right)$ : unbonded distance in hydrogen bonded $\mathrm{NH}$ group/water, $\mathrm{d}_{\mathrm{O}-\mathrm{O}}$ : unbonded distance in hydrogen bonded water/water). 
Table 3. Examples of conformation energies $\left(E_{c}\right)$ (Model: No. 2 (h= 0.5, hydrtate type: $\left.\alpha\right)$, by RHF/6-31G).

\begin{tabular}{|c|c|c|c|c|c|c|c|c|}
\hline \multirow{3}{*}{ Conformations } & \multirow{3}{*}{$\mathrm{E}_{\mathrm{h}}(\mathrm{HF})$} & \multicolumn{6}{|c|}{ Water molecules } & \multirow{3}{*}{$\mathrm{E}_{\mathrm{c}}(\mathrm{HF})$} \\
\hline & & \multirow{2}{*}{$\begin{array}{l}\text { Number of } \\
\text { water }\left(\mathrm{N}_{\mathrm{w}}\right)^{1}\end{array}$} & \multicolumn{2}{|c|}{ Non-hydrogen bonds } & \multicolumn{2}{|c|}{ Hydrogen bonds } & \multirow{2}{*}{$\sum \mathrm{E}_{\mathrm{w}}(\mathrm{HF})$} & \\
\hline & & & $\mathrm{N}_{\mathrm{w}(\mathrm{n})}{ }^{2}$ & $\mathrm{E}_{\mathrm{w}(\mathrm{n})}(\mathrm{HF})$ & $\mathrm{N}_{\mathrm{w}(\mathrm{h})}{ }^{4}$ & $\mathrm{E}_{\mathrm{w}(\mathrm{h})}(\mathrm{HF})^{3}$ & & \\
\hline$(\mathrm{ttt})_{5}$ & -1027.2999 & 3 & 3 & -227.9562 & 0 & 0 & -227.9562 & -799.3437 \\
\hline$\left(\operatorname{tg}^{+} t\right)_{5}$ & -1027.3266 & 3 & 1 & -75.9854 & 2 & -151.9826 & -227.9680 & -799.3586 \\
\hline
\end{tabular}

${ }^{1} \mathrm{~N}_{\mathrm{w}}=\mathrm{N}_{\mathrm{w}(\mathrm{n})}+\mathrm{N}_{\mathrm{w}(\mathrm{h}) \cdot}{ }^{2}$ Number of water molecules with non-hydrogen bond ( $\mathrm{d}_{\mathrm{O}-\mathrm{O}} \geq 3 \AA$ ), obtained in Figure 2 or 3. ${ }^{3}$ From Table 2. ${ }^{4}$ Number of water molecules with hydrogen bond $\left(\mathrm{O} \cdots \mathrm{H}, \mathrm{d}_{\mathrm{O}-\mathrm{O}}<3 \AA\right)$, obtained in Figure 2 or 3.

Table 4. Structure analyses for hydrate models of ethyleneimine oligomer (EI 5-mer) by RHF/6-31G.

\begin{tabular}{|c|c|c|c|c|c|c|c|c|c|}
\hline & Models & No.1 & No.2 & No.3 & No.4 & No.5 & No.6 & No. 7 & No.8 \\
\hline & $\begin{array}{l}\text { Number of } \\
\text { water: } \mathrm{N}_{\mathrm{w}}\end{array}$ & 0 & 3 & 3 & 4 & 5 & 6 & 9 & 12 \\
\hline & $\begin{array}{l}\text { Hydrate } \\
\text { ratios: h }\end{array}$ & 0 & $0.5(\alpha)$ & $0.5(\beta)$ & $0.67(\beta)$ & $0.83(\beta)$ & $1(\beta)$ & $1.5(\beta)$ & $2(\beta)$ \\
\hline \multirow{10}{*}{$(\mathrm{ttt})_{5}$} & $\mathrm{E}_{\mathrm{h}}(\mathrm{HF})$ & -799.3040 & -1027.2999 & -1027.2990 & -1103.2996 & -1179.2976 & -1255.2968 & -1483.3103 & -1711.3289 \\
\hline & $\mathrm{N}_{\mathrm{w}(\mathrm{n})} / \mathrm{N}_{\mathrm{w}(\mathrm{h})}$ & - & $3 / 0$ & $3 / 0$ & $4 / 0$ & $5 / 0$ & $6 / 0$ & $3 /(2 \times 3)$ & $0 /(2 \times 6)$ \\
\hline & $\mathrm{N}_{\mathrm{w}\left(\mathrm{h}^{\prime}\right)}{ }^{1}$ & - & 3 & 3 & 4 & 5 & 6 & 6 & 6 \\
\hline & $\sum \mathrm{E}_{\mathrm{w}}(\mathrm{HF})$ & - & -227.9562 & -227.9562 & -303.9416 & -379.9274 & -455.9128 & -683.9040 & -911.8956 \\
\hline & $\mathrm{E}_{\mathrm{c}}(\mathrm{HF})$ & -799.3040 & -799.3437 & -799.3428 & -799.3580 & -799.3702 & -799.3840 & -799.4063 & -799.4333 \\
\hline & $\begin{array}{c}\Delta \mathrm{E}_{\mathrm{c}} \\
(\mathrm{kcal} / \mathrm{m} \cdot \text { u. })^{2}\end{array}$ & 0.00 & -4.98 & -4.87 & -6.78 & -8.31 & -10.1 & 12.8 & -16.2 \\
\hline & $\tau_{\mathrm{n}}\left({ }^{\circ}\right)^{3}$ & -180.0 & -179.6 & 179.1 & -178.7 & 178.4 & 179.0 & 177.9 & 179.3 \\
\hline & $\begin{array}{c}\mathrm{N}-\mathrm{H}^{\prime}{ }_{\mathrm{N}} / / \\
\mathrm{N}^{\prime}-\mathrm{H}_{\mathrm{N}}(\AA)^{4}\end{array}$ & $4.01 / 4.01$ & $4.01 / 4.02$ & $4.01 / 4.01$ & $4.02 / 4.02$ & $4.01 / 4.01$ & $4.02 / 4.02$ & $4.01 / 4.00$ & $4.00 / 4.00$ \\
\hline & $\begin{array}{c}2 \text { mol length } \\
(\AA)^{5}\end{array}$ & 7.35 & 7.35 & 7.37 & 7.38 & 7.38 & 7.37 & 7.37 & 7.37 \\
\hline & $\mathrm{L}(\AA)$ & 18.38 & 18.31 & 18.41 & 18.42 & 18.43 & 18.44 & 18.42 & 18.44 \\
\hline \multirow{11}{*}{$\left(\operatorname{tg}^{+} t\right)_{5}$} & $\mathrm{E}_{\mathrm{h}}(\mathrm{HF})$ & -799.3183 & -1027.3266 & -1027.3299 & -1103.3372 & -1179.3459 & -1255.3603 & -1483.3851 & -1711.4103 \\
\hline & $\mathrm{N}_{\mathrm{w}(\mathrm{n})} / \mathrm{N}_{\mathrm{w}(\mathrm{h})}$ & - & $1 / 2$ & $0 / 3$ & $0 / 4$ & $0 / 5$ & $0 / 6$ & $0 / 9$ & $0 / 12$ \\
\hline & $\mathrm{N}_{\mathrm{w}\left(\mathrm{h}^{\prime}\right)}{ }^{1}$ & - & 3 & 2 & 3 & 4 & 4 & 5 & 5 \\
\hline & $\sum \mathrm{E}_{\mathrm{w}}(\mathrm{HF})$ & - & -227.9680 & -227.9830 & -303.9850 & -379.9876 & -455.9907 & -684.0007 & -912.0114 \\
\hline & $\mathrm{E}_{\mathrm{c}}(\mathrm{HF})$ & -799.3183 & -799.3586 & -799.3467 & -799.3522 & -799.3583 & -799.3696 & -799.3844 & -799.3989 \\
\hline & $\begin{array}{c}\Delta \mathrm{E}_{\mathrm{c}} \\
(\mathrm{kcal} / \mathrm{m} \cdot \text { u. })^{2}\end{array}$ & -1.79 & -6.85 & -5.36 & -6.05 & -6.81 & -8.23 & -10.1 & -11.9 \\
\hline & $\tau_{\mathrm{n}}\left({ }^{\circ}\right)^{3}$ & 62.7 & 66.5 & 61.5 & 59.9 & 61.6 & 62.3 & 56.7 & 58.7 \\
\hline & $\begin{array}{c}\mathrm{N}-\mathrm{H}^{\prime}{ }_{\mathrm{N}}^{\prime} / \\
\mathrm{N}^{\prime}-\mathrm{H}_{\mathrm{N}}(\AA)^{4}\end{array}$ & $2.48 / 3.2$ & $2.74 / 3.18$ & $2.57 / 3.15$ & $2.58 / 3.08$ & $3.68 / 3.12$ & $2.69 / 3.17$ & $2.61 / 2.98$ & $2.54 / 3.02$ \\
\hline & $\begin{array}{c}5 \text { mol length } \\
(\AA)^{5}\end{array}$ & 13.90 & 7.82 & 13.44 & 12.07 & 12.09 & 6.91 & 10.10 & 11.30 \\
\hline & $\mathrm{L}(\AA)$ & 13.57 & 8.66 & 12.93 & 11.84 & 11.93 & 6.99 & 10.81 & 11.59 \\
\hline & $\mathrm{D}(\AA)$ & 1.0 & 1.94 & 1.23 & 1.57 & 1.57 & 1.91 & 1.60 & 1.43 \\
\hline
\end{tabular}

${ }^{1}$ Number of water molecules with hydrogen bond $\left(\mathrm{N} \cdots \mathrm{H}, \mathrm{d}_{\mathrm{N}-\mathrm{H}}<2 \AA\right.$ and $\mathrm{d}_{\mathrm{N}-\mathrm{O}}<3 \AA$ ) between imino group and water. ${ }^{2} \mathrm{Based}$ on $\mathrm{E}_{\mathrm{c}}$ of $(\mathrm{ttt})_{5}$ conformer with $\mathrm{h}=$ 0 . $^{3}$ Average of dihedral angles for C-C bonds. ${ }^{4} \mathrm{~N}-\mathrm{H}^{\prime}{ }_{\mathrm{N}}$ ' (or N'- $\mathrm{H}_{\mathrm{N}}$ ) is average of unbonded distance between $\mathrm{N}$ of $\mathrm{NH}$ group and $\mathrm{H}^{\prime}$ of neighboring $\mathrm{N}$ ' $\mathrm{H}$ ' group (or between $\mathrm{N}$ ' and $\mathrm{H}$ ). ${ }^{5}$ Average value.

former will be defined as the smallest value of the summation of anhydrate energy and hydration stability en- ergy [19]. The hydration stability energy $\left(\Delta E_{c}, \mathrm{kcal} / \mathrm{m} . \mathrm{u}\right.$., m.u.: monomer unit) is given as the difference between 
Table 5. Comparison between the calculated and observed structures.

\begin{tabular}{|c|c|c|c|c|c|c|}
\hline & \multirow{2}{*}{\multicolumn{3}{|c|}{ Calculated for hydrate models of $(\mathrm{ttt})_{5}$ conformer }} & \multicolumn{3}{|c|}{ Observed for hydrous linear PEI crystals (by XRD $[2,3]$ ) } \\
\hline & & & & \multirow{2}{*}{$\begin{array}{c}\text { Hemi-hydrate [2] } \\
\mathrm{h}^{\prime}=0.5^{1}\end{array}$} & \multirow{2}{*}{$\begin{array}{c}\text { Sesqui-hydrate [3] } \\
\mathrm{h}^{\prime}=1.5^{1}\end{array}$} & \multirow{2}{*}{$\begin{array}{c}\text { Di-hydrate [3] } \\
\mathrm{h}^{\prime}=2^{1}\end{array}$} \\
\hline & $\mathrm{h}=0.5(\alpha)$ & $\mathrm{h}=1.5(\beta)$ & $\mathrm{h}=2(\beta)$ & & & \\
\hline Conformation & all trans & all trans & all trans & all trans & all trans & all trans \\
\hline 2 mol length $(\AA)$ & 7.35 & 7.37 & 7.37 & $7.31^{2}$ & $7.36^{2}$ & $7.36^{2}$ \\
\hline \multirow{2}{*}{$\mathrm{d}_{\mathrm{N}-\mathrm{O}}(\AA)$} & 2.88 & 2.87 & 2.81 & $3.05\left(\mathrm{~N}_{\mathrm{a}} \cdots \mathrm{O}_{1}\right)$ & $2.96\left(\mathrm{~N}_{\mathrm{a}} \cdots \mathrm{O}_{1}\right)$ & $2.93\left(\mathrm{~N}_{\mathrm{a}} \cdots \mathrm{O}_{1}\right)$ \\
\hline & & & & $2.87\left(\mathrm{~N}_{\mathrm{a}}, \cdots \mathrm{O}_{1}\right)$ & $2.93\left(\mathrm{~N} \cdots \mathrm{O}_{3}\right)$ & \\
\hline \multirow{3}{*}{$\mathrm{d}_{\mathrm{O}-\mathrm{O}}(\AA)$} & $--^{3}$ & 2.72 & 2.81 & $--^{3}$ & $2.87\left(\mathrm{O}_{1} \cdots \mathrm{O}_{2}\right)$ & $2.66\left(\mathrm{O}_{1} \cdots \mathrm{O}_{2}\right)$ \\
\hline & & & & -3 & $2.80\left(\mathrm{O}_{1} \cdots \mathrm{O}_{3}\right)$ & \\
\hline & & & & $-3^{3}$ & $2.79\left(\mathrm{O}_{1} \cdots \mathrm{O}_{4}\right)$ & $2.75\left(\mathrm{O}_{1} \cdots \mathrm{O}_{4}\right)$ \\
\hline
\end{tabular}

${ }^{1} \mathrm{~h}^{\prime}: \mathrm{H}_{2} \mathrm{O} / \mathrm{EI}(\mathrm{mol}){ }^{2}$ Fiber period, corresponding to $2 \mathrm{~mol}$ length. ${ }^{3} \mathrm{Hydrogen}$ bondings between water molecules were not estimated or observed.

the $E_{c}$ values of anhydrate and hydrate. The results are shown in Table 4. In Figure 4, the relations between $\Delta E_{c}$ and $\mathrm{h}$ values are shown. The $\Delta E_{c}$ values decreased linearly with increases of water contents. In Figure 5, the $N_{w\left(h^{\prime}\right)}$ values (with $\mathrm{N} \cdots \mathrm{H}$ bond) are plotted against hydrate ratios $(\mathrm{h})$. The $N_{w(h)}$ values increase with increases of $h$ values until $h=1\left((t t t)_{5}\right)$ or $1.5\left(\left(\operatorname{tg}^{+} t\right)_{5}\right)$. These results indicate that the conformers are stabilized by an electrostatic effect of $\mathrm{N} \cdot \mathrm{H}$ bond.

In $(\mathrm{ttt})_{5}$ conformers, as shown in Figure 4, the $\Delta E_{c}$ values of two conformers with $h=0.5$ of $\alpha$ and $\beta$ (continuous) hydrate type, which have the same value (3) of $N_{w(h ')}$ (Figure 5), are almost the same. This result indicates that the chain torsion effects on $\Delta E_{c}$ in $(\mathrm{ttt})_{5}$ conformers seem to be little because of the long distance between neighboring $\mathrm{NH}$ groups in stretched trans structure $\left(\mathrm{N}-\mathrm{H}^{\prime}{ }_{\mathrm{N}}\right.$, or $\mathrm{N}^{\prime}-\mathrm{H}_{\mathrm{N}}$ : $4.01 \AA$, see Table 4). Although the $N_{w(h)}$ values of $(\mathrm{ttt})_{5}$ conformers with $\mathrm{h}=1.5$ and 2 are the same (6) as that with $\mathrm{h}=1$ (Figure 5), the $\Delta E_{c}$ values of the formers are smaller than that of the latter(Figure 4). It seems to be related with the results that the pairs of water molecules at $\mathrm{h}=1.5$ or 2 are located in series to each $\mathrm{NH}$ group with $\mathrm{O} \cdots \mathrm{H}$ bonds as shown in Figure 2.

In $\left(\operatorname{tg}^{+} t\right)_{5}$ conformers, as shown in Figure 4, the plots of $\Delta E_{c}$ against $\mathrm{h}$ values show linear relation and the conformers are stabilized by hydration as same as in $(\mathrm{ttt})_{5}$ conformers. However, $\Delta E_{c}$ values in h over 0.5 are larger than those of $(\mathrm{ttt})_{5}$ conformers. From an energy aspect, this result corresponds to the experimental results observed for linear PEI's crystals in hydration process. The instability of $\left(\operatorname{tg}^{+} t\right)_{5}$ conformers seems to be related with both the increases of $\mathrm{O} \cdots \mathrm{H}$ bonds and the decreases of $\mathrm{N} \cdots \mathrm{H}$ bonds. In $\left(\operatorname{tg}^{+} \mathrm{t}\right)_{5}$ conformers, the $N_{w(h)}$ values with $\mathrm{O} \cdots \mathrm{H}$ bond increased with increases of $\mathrm{h}$ values as shown in Figure 3 and Table 4. And at the same time, the $N_{w\left(h^{\prime}\right)}$

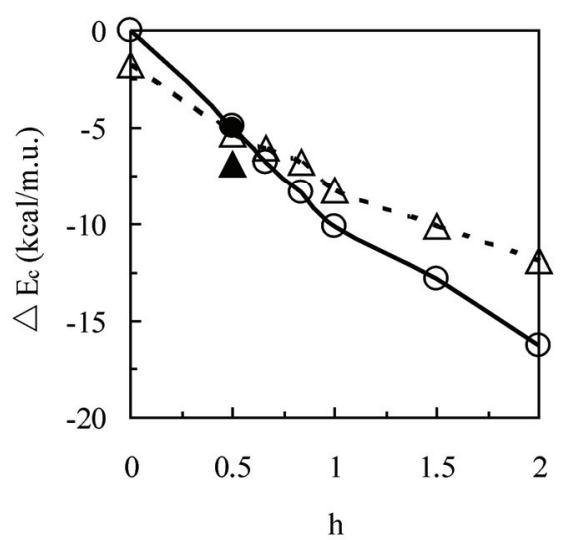

Figure 4. Plots of hydration stability energy $\left(\Delta E_{c}, k c a l / m . u.\right)$ against hydrate ratios $(\mathrm{h})$. The $\bullet$ and $\circ$ symbols show $(\mathrm{ttt})_{5}$ conformers with $\alpha$ and $\beta$ type, respectively. $\Delta$ and $\Delta$ show $\left(\operatorname{tg}^{+} t\right)_{5}$ conformers with $\alpha$ and $\beta$ type, respectively.

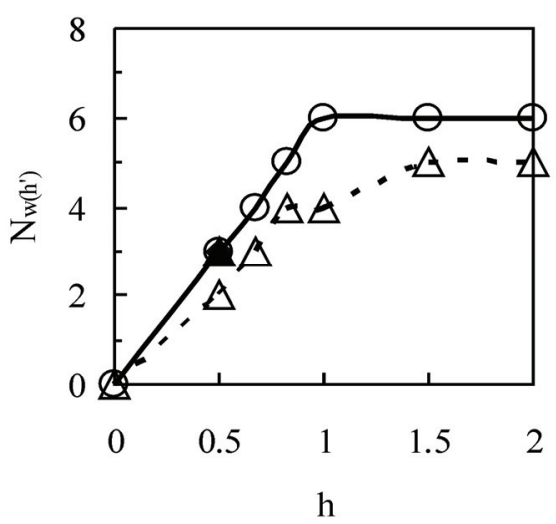

Figure 5. Plots of $N_{w(h ')}$ against hydrate ratios (h). The • and $\odot$ symbols show $(\mathrm{ttt})_{5}$ conformers with $\alpha$ and $\beta$ type, respectively. The $\Delta$ and $\Delta$ symbols show $\left(\operatorname{tg}^{+} t\right)_{5}$ conformers with $\alpha$ and $\beta$ type, respectively. 
values with $\mathrm{N} \cdots \mathrm{H}$ bond are smaller than those of $(\mathrm{ttt})_{5}$ conformers as shown in Figure 5. As shown in Table 4, the $\mathrm{N} \cdots \mathrm{H}$ bond distances $\left(\mathrm{N}-\mathrm{H}^{\prime}\right.$, or $\left.\mathrm{N}^{\prime}-\mathrm{H}_{\mathrm{N}}\right)$ in neighboring $\mathrm{NH}$ groups of anhydrated $\left(\operatorname{tg}^{+} \mathrm{t}\right)_{5}$ conformer are smaller $(0.7-1.2 \AA)$ than those of $(\mathrm{ttt})_{5}$ conformer. Anhydrous PEI's chain (tgt) is strongly twisted by intra- and inter-molecular interactions $(\mathrm{N} \cdots \mathrm{H}$ bonding between imino groups). Taking into account of these results, the water molecules coming near to NH groups of $\left(\operatorname{tg}^{+} \mathrm{t}\right)_{5}$ conformer must strongly prefer to having a pair with $\mathrm{O} \cdots \mathrm{H}$ bonds between water molecules compared with $(\mathrm{ttt})_{5}$ conformer. For examples in $\mathrm{h}=0.5$, as shown in Table 4, the $N_{w(h)}$ values of $\left(\operatorname{tg}^{+} \mathrm{t}\right)_{5}$ conformers with $\alpha$ and $\beta$ type are larger (2-3) than those of (ttt) $)_{5}$ conformers with $\alpha$ and $\beta$ type. Furthermore, the $N_{w(h)}$ value of $\left(\operatorname{tg}^{+} \mathrm{t}\right)_{5}$ conformer with $\beta$ type is larger (1) than that with $\alpha$ type.

\subsection{Structures Calculated for Hydrate Models of $(t t t) 5$ and $(t g+t) 5$ Conformers}

In $(\mathrm{ttt})_{5}$ conformers, as shown in Figure 2 and Table 4, the structure changes by hydrations are little. It seems to be related with the results that the effects of $\mathrm{O} \cdots \mathrm{H}$ bonds between water molecules on the structures are negligible. The $\mathrm{O} \cdots \mathrm{H}$ bonds were not found in conformers with $\mathrm{h} \leq$ 1 , but were found in the conformers with $\mathrm{h}=1.5$ and 2 . In $\mathrm{h}=1.5$ and 2 , the $\mathrm{O} \cdots \mathrm{H}$ bonds are independent in each hydrate unit (refer Figure 2).

In Table 5, the structures calculated for $(\mathrm{ttt})_{5}$ conformers were compared with those observed for linear hydrous PEI's crystals by XRD [2,3]. The 2 mol length or $\mathrm{d}_{\mathrm{N}-\mathrm{O}}$ value calculated for the conformers with $\mathrm{h}=0.5$ $(\alpha, \beta$ type), 1.5 and 2 agreed in that observed for hemi$\left(\mathrm{H}_{2} \mathrm{O} / \mathrm{EI}\right.$, mol $\left.=0.5\right)$ [2], sesqui- (1.5) [3] and di-hydrate (2) [3], respectively. The results that the $\mathrm{O} \cdots \mathrm{H}$ bonds between water molecules were not found in the conformers with $h=0.5$ ( $\alpha$ and $\beta$ type) corresponded to the experimental results observed for hemi-hydrate as shown in Table 5. The $\mathrm{d}_{\mathrm{O}-\mathrm{O}}$ values calculated for the $\mathrm{O} \cdots \mathrm{H}$ bonded water molecules in conformers with $\mathrm{h}=1.5$ and 2 agreed in those observed for sesqui- [3] and di-hydrate [3]. These agreements in the calculated and observed results should be noticed. Polymer chains in hydrous crystal are separated to a single chain (ttt) with hydrogen bonded water molecule ( $\mathrm{N} \cdots \mathrm{H}$ and/or $\mathrm{O} \cdots \mathrm{H}$ bond). The structures calculated for single chain models will be fundamentally different from those observed for hydrous polymer crystals. These agreements seem to be resulted in "a single chain" in both cases.

As shown in Figure 3, the structure calculated for anhydrate model of $\left(\operatorname{tg}^{+} t\right)_{5}$ conformer fundamentally corresponded to the structure observed for anhydrous linear PEI's crystal (5/1 double stranded helix, tgt [1]). However, the 5 mol length calculated (13.90 $\AA$, in Table 4) was different from that observed (9.58 $\AA$ [1]). This difference indicates that the double stranded helical chains of PEI are largely shrinking and swelling because of their inter-molecular interactions. The structures calculated for hydrate models of $\left(\operatorname{tg}^{+} t\right)_{5}$ conformer largely changed by hydrations as shown in Figure 3 and Table 4. The plots of shrinkage rates $\left(\Delta \mathrm{L} / \mathrm{L}_{0}(\%), \mathrm{L}_{0}\right.$ : conformer length calculated for anhydrate) against $h$ values are shown in Figure 6. In Figure 7, the swelling rates in $\left(\operatorname{tg}^{+} t\right)_{5}$ conformers $\left(\Delta \mathrm{D} / \mathrm{D}_{0}(\%), \mathrm{D}_{0}\right.$ : diameter calculated for anhydrate) are plotted against $h$ values. As shown in Figures 6 and 7 , the $\left(\operatorname{tg}^{+} \mathrm{t}\right)_{5}$ conformers with $\mathrm{h}=0.5$ ( $\alpha$ type) and 1 ( $\beta$ type) are strongly shrinking and swelling. It seems to be connected with the results that the water molecules with $\mathrm{O} \cdots \mathrm{H}$ bonds are located in the insides of conformers as shown in Figure 3. Taking into account with the results of $\Delta E_{c}$ (Figure 4), the strong swelling in $\left(\operatorname{tg}^{+} \mathrm{t}\right)_{5}$

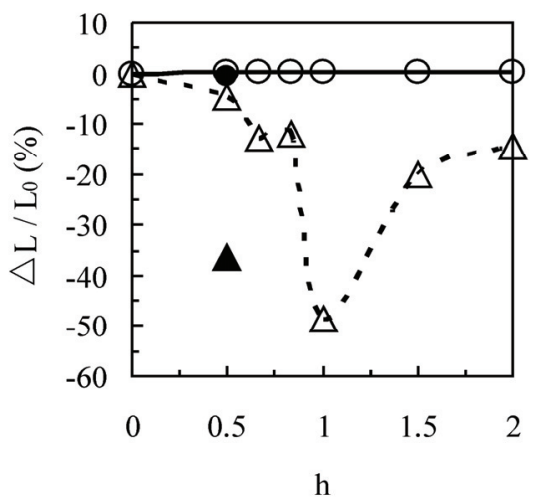

Figure 6. Plots of chain shrinkage rates $\left(\Delta L / L_{0}(\%), \Delta L: L\right.$ $L_{0}, L_{0}: L$ of anhydrate) against hydrate ratios (h). The $\bullet$ and $\odot$ symbols show $(\mathrm{ttt})_{5}$ conformers with $\alpha$ and $\beta$ type, respectively. The $\Delta$ and $\Delta$ symbols show $\left(\operatorname{tg}^{+} t\right)_{5}$ conformers with $\alpha$ and $\beta$ type, respectively.

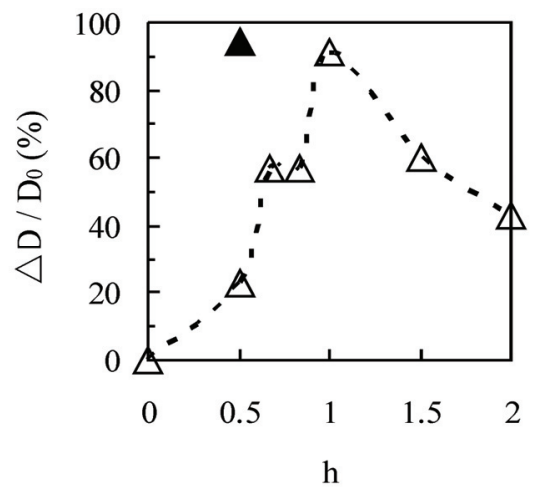

Figure 7. Plots of chain swelling rates $\left(\Delta D / D_{0}(\%), \Delta D: D\right.$ $D_{0}, D_{0}$ : D of anhydrate) against hydrate ratios $(h)$ in $\left(\operatorname{tg}^{+} t\right)_{5}$ conformers. The $\Delta$ and $\Delta$ symbols show $\alpha$ and $\beta$ type, respectively. 
conformers with $h$ values over 0.5 may be one of the driving forces for dissociation from a double helical chain to a single planar chain of PEI's crystal or other polymer chains as DNA in hydration process.

\section{Conclusions}

Structure analyses for hydrate models of EI 5-mer as a PEI's model were investigated by QCC. In anhydrates, $\left(\operatorname{tg}^{+} \mathrm{t}\right)_{5}$ conformer was more stable than $(\mathrm{ttt})_{5}$ conformer. In hydrates with hydrate ratios $(\mathrm{h})$ over 0.5 , $(\mathrm{ttt})_{5}$ conformers were more stable than $\left(\operatorname{tg}^{+} t\right)_{5}$ conformers with increases of $h$ values. From an aspect of conformation energy, these results corresponded to the experimental results that the structure of anhydrous linear PEI's crystal changes from helix (tgt) to planar zigzag (ttt) in hydration process. Structures calculated for hydrates of $(\mathrm{ttt})_{5}$ conformers agreed in those observed for hydrous PEI crystals. The instabilities (higher $E_{c}$ ) and structure changes (swelling) which were estimated for $\left(\operatorname{tg}^{+} \mathrm{t}\right)_{5}$ conformers with hydrate ratios over 0.5 were strongly connected with the formation of $\mathrm{O} \cdots \mathrm{H}$ bonds between water molecules affected by the chain torsion, and may be one of the driving forces for the dissociation of double helical chains of PEI in hydration process.

\section{REFERENCES}

[1] Y. Chatani, T. Kobatake, H. Tadokoro and R. Tanaka, "Structure Studies of Poly(ethyleneimine). 2. DoubleStranded Helical Chain in the Anhydrate," Macromolecules, Vol. 15, No. 1, 1982, pp. 170-176.

[2] Y. Chatani, T. Kobatake and H. Tadokoro, "Structure Studies of Poly(ethyleneimine). 3. Structural Characterization of Anhydrous and Hydrous States and Crystal Structure of the Hemihydrate," Macromolecules, Vol. 16, No. 2, 1983, pp. 199-204.

[3] Y. Chatani, H. Tadokoro, T. Saegusa and H. Ikeda, "Structure Studies of Poly(ethyleneimine). 1. Structures of Two Hydrates of Poly(ethyleneimine): Sesquihydrate and Dihydrate," Macromolecules, Vol. 14, No. 2, 1981, pp. 315-321.

[4] T. Hashida, K. Tashiro, S. Aoshima and Y. Inaki, "Structural Investigation on Water-Induced Phase Transitions of Poly(ethyleneimine). 1. Time-Resolved Infrared Spectral Measurements in the Hydration Process," Macromolecules, Vol. 35, No. 11, 2002, pp. 4330-4336.

[5] H. Dong, J. K. Hyun, C. Durham and R. A. Wheeler, "Molecular Dynamics Simulations and Poly(ethyleneimine) Models," Polymer, Vol. 42, No. 18, 2001, pp. 7809-7817.
[6] S. Wang, L. DeBolt and J. E. Mark, "Configurational Analysis of Linear Poly(ethyleneimine)," Polymeric Preprints, Vol. 34, No. 2, 1993, pp. 478-479.

[7] S. E. Boesch, S. S. York, R. Frech and R. A. Wheeler, "An Experimental and Computational Investigation of the Structure and Vibrations of Dimethylethylenediamine, a Model for Poly(ethyleneimine)," PhysChemComm, Vol. 4, 2001, pp. 1-10.

[8] Y. Sasanuma, S. Hattori, S. Imazu, S. Ikeda, T. Kaizuka, T. Iijima, M. Sawanobori, M. A. Azam, R. V. Law and J. H. G. Steinke, "Conformational Analysis of Poly(ethyleneimine) and its Model Compounds: Rotational and Inversional Isomerizations and Intramolecular and Intermolecular Hydrogen Bonds," Macromolecules, Vol. 37, No. 24, 2004, pp. 9169-9183.

[9] H. Kusanagi, "Quantum Chemical Examination on the Double-Stranded Helix Models of Poly(ethyleneimine)," Polymer Preprints Japan, Vol. 53, No. 2, 2004, pp. 3610-3611.

[10] D. Diabate, A. Yapo, A. Trokourey, A. Kone and B. Fahys, "Study of Structural and Electronic Properties of Polyethylenimine Hemihydrate," Physical and Chemical News, Vol. 37, 2007, pp. 122-126.

[11] M. Kobayashi and H. Sato, "Conformational Analysis of Ethylene Oxide and Ethylene Imine Oligomers by Quantum Chemical Calculation," Polymer Journal, Vol. 40, No. 4, 2008, pp. 343-349.

[12] M. Kobayashi and H. Sato, "Conformational Analysis of Ethylene Oxide and Ethylene Imine Oligomers by Quantum Chemical Calculations: Solvent Effects," Polymer Bulletin, Vol. 61, No. 4, 2008, pp. 529-540.

[13] M. Kobayashi, M. Takahashi and H. Sato, "Conformational Analysis for Hydrated Ethylene Imine Oligomer Models by Quantum Chemical Calculations," Polymer Journal, Vol. 41, No. 10, 2009, pp. 880-887.

[14] Gaussian Inc., "Gaussian 03 User's Reference," Gaussian Inc., Pennsylvania, 2003.

[15] R. Ludwig, "Water from Clusters to the Bulk," Angewandte Chemie International Edition, Vol. 40, No. 10, 2001, pp. 1808-1827.

[16] T. R. Dyke, K. M. Mack and J. S, Muenter, J. Chem. Phys., Vol. 66, 1977, pp. 498.

[17] J. A. Odutola and T. R. Dyke, "Nitric Acid and Carboxylic Acid Dimers," Journal of Chemical Physics, Vol. 72, 1980, pp. 50-62.

[18] D. R. Lide, "CRC Handbook of Chemistry and Physics," 82nd Edition, CRC Press, London, 2001.

[19] M. Kinoshita, Y. Okamoto and F. Hirata, "Solvent Effects on Formation of Tertiary Structure of Protein," Biophysical Society of Japan, Vol. 40, No. 6, 2000, pp. 374-378. 